NR 853 EKONOMICZNE PROBLEMY TURYSTYKI NR 2 (30) 2015

\title{
Piotr Zawadzki*
}

Uniwersytet Ekonomiczny we Wrocławiu

\section{ORGANIZACJA MASOWYCH IMPREZ SPORTOWYCH JAKO FORMA PROMOCJI OŚRODKÓW TURYSTYCZNYCH NA PRZYKŁADZIE LETNIEGO BIEGU PIASTÓW W JAKUSZYCACH}

\begin{abstract}
Streszczenie
Celem artykułu jest pokazanie możliwości promocji produktu turystycznego przy wykorzystaniu nowoczesnej formy, jaką jest event marketing. Na wstępie, w części teoretycznej artykułu, zaprezentowano problematykę turystyki usportowionej, jej podobieństw ze sportem oraz turystyką kwalifikowaną. Autor przedstawił również istotę oraz cechy działań związanych z marketingiem wydarzeń. W dalszej części zaprezentował charakterystykę Jakuszyc - najbardziej popularnego ośrodka narciarstwa biegowego w Polsce oraz Stowarzyszenia Biegu Piastów - organizatora największych imprez sportowych na terenie Polany Jakuszyckiej. W końcowej części zaprezentowano działania związane z organizacją Letniego Biegu Piastów i wpływ tej imprezy na rozwój turystyki w Jakuszycach w sezonie letnim.
\end{abstract}

Słowa kluczowe: promocja turystyki, turystyka kwalifikowana, event marketing, Letni Bieg Piastów

\section{Wprowadzenie}

Znamiennym zjawiskiem życia społecznego ostatnich lat jest ciagły wzrost ilości wolnego czasu. Postęp i wynikające z niego wszelkie udogodnienia życia powodują, że czas wolny w dużej mierze przeznaczany jest na wypoczynek i rekreację,

\footnotetext{
* Adres e-mail: piotr.zawadzki@ue.wroc.pl.
} 
a także łączy ze sobą elementy odprężenia z różnymi formami aktywności umysłowej i fizycznej. Współczesne tendencje wpływają stopniowo również na zmiany sposobów wypoczywania. Coraz więcej sympatyków zyskują zatem aktywne formy wypoczynku, tj. uprawianie sportu, turystyka kwalifikowana czy krajoznawcza.

Promocja przez turystykę aktywną jest działaniem pożądanym z kilku powodów. Jednym z czynników wpływających na rozwój turystyki jest zmiana stylu życia wyrażająca się zmianą stosunku do pracy i czasu wolnego. Coraz więcej ludzi będzie żyć nie tylko po to, aby pracować, ale pracować po to, aby móc realizować swoje marzenia w czasie wolnym ${ }^{1}$.

\section{Turystyka usportowiona na styku sportu i turystyki kwalifikowanej}

Kontakt z naturą jako istotny element turystyki związany jest z pozytywnym wpływem na ciało turysty takich czynników, jak: światło słoneczne, zmienne ciśnienie atmosferyczne, wysoka lub niska temperatura oraz zmienna wilgotność powietrza. Czynniki te sprzyjają hartowaniu organizmu człowieka, który coraz częściej pracuje, przemieszcza się i odpoczywa w zamkniętej (często klimatyzowanej lub ogrzewanej) przestrzeni. Istotne znaczenie dla psychiki turysty ma także bezpośredni kontakt $\mathrm{z}$ walorami przyrody, takimi jak: cechy estetyczne i kulturowe krajobrazu, unikatowa roślinność, obserwowanie zwierząt. Pozwala to na odprężenie i może zapobiegać depresji oraz innym chorobom wynikającym z postępu cywilizacji ${ }^{2}$.

Turystyka aktywna staje się jedną z najdynamiczniej rozwijających się form turystyki, gdyż jej cechą jest podejmowanie różnego rodzaju aktywności fizycznej ukierunkowanej na rozwój sprawności fizycznej i poprawę zdrowia. Można zatem turystykę aktywną traktować jako pierwszy etap turystyki kwalifikowanej, na tyle nieskomplikowany pod względem wymaganych umiejętności i sprawności psychofizycznej, by był dostępny dla wszystkich chętnych niezależnie od predyspozycji i stanu zdrowia.

Przez turystykę aktywną rozumiemy wszelkiego rodzaju wyjazdy jednoi wielodniowe, których głównym celem jest podejmowanie aktywności fizycznej

\footnotetext{
1 R. Winiarski, J. Zdebski, Psychologia turystyki, Wydawnictwa Akademickie i Profesjonalne, Warszawa 2008, s. 25.

2 R. Tomik, A. Hadzik, J. Cholewa, Turystyka aktywna w materiałach promocyjnych województw w Polsce, w: Wyzwania współczesnej polityki turystycznej. Problemy polityki turystycznej, red. A. Rapacz, Wyd. UE we Wrocławiu, Wrocław 2012, s. 17.
} 
(uprawianie różnych form rekreacji ruchowej). Cechą odróżniającą turystykę aktywną od rekreacji ruchowej jest opuszczenie miejsca stałego zamieszkania i wejście w interakcję ze środowiskiem naturalnym. Podstawowymi formami turystyki aktywnej są: turystyka kwalifikowana, przygodowa i ekstremalna. Główne rodzaje turystyki kwalifikowanej to wszelkiego rodzaju wędrówki piesze, turystyka rowerowa, spływy kajakowe, rejsy żeglarskie, turystyka jeździecka, wyjazdy na narty $i$ inne rodzaje związane z wysiłkiem fizycznym w plenerze ${ }^{3}$.

Wzrost zainteresowania turystyką kwalifikowaną jest w dużym stopniu uwarunkowany modą na aktywne formy wypoczynku. Współczesną cechą turystyki kwalifikowanej staje się samodzielność turysty, która z kolei jest odbiciem światowych trendów w turystyce. Turystyka kwalifikowana jest doskonała formą zagospodarowania czasu wolnego, a na jej rozpowszechnienie wpływ ma: dostępna baza turystyczna, sprawna komunikacja, dobra informacja turystyczna oraz coraz lepsze wyposażenie ośrodków turystycznych nie tylko w sprzęt, ale także dostępność do dobrze wyszkolonej kadry i organizatorów ruchu turystyki kwalifikowanej. Rozsądnie uprawiany sport oraz turystyka służą celom społecznie wartościowym, jak i wychowawczym. Turystyka kwalifikowana może być nośnikiem następujących walorów ${ }^{4}$ :

a) wzbogacania wiedzy o kraju (walor poznawczy);

b) zaspokajania potrzeb emocjonalnych (walor emocjonalny);

c) rozwijania umiejętności o charakterze technicznym i wiedzy o poruszaniu się w terenie (walor różnorodnych umiejętności);

d) zaspokajania potrzeb biologicznego minimum aktywności zawodowej (walor zdrowotny);

e) kształtowania pozytywnych cech charakteru (walor wychowawczy).

Istotnym elementem turystyki kwalifikowanej jest również to, że elementy konkurencji sportowych lub współzawodnictwa wplecione w programy imprez turystyki, podnosząc jej atrakcyjność, dają możliwość „wyżycia się” tym uczestnikom, których oprócz sformułowań krajoznawczych pasjonuje też sportowa rywalizacja ${ }^{5}$.

3 Ibidem, s. 18.

4 J. Merski, Wplyw uprawiania turystyki kwalifikowanej przez ludzi dorostych na ich sprawność motorycznq, Almamer, Warszawa 2007, s. 26.

5 Ibidem, s. 25. 
Przez turystykę usportowioną należy zatem rozumieć zamiennie turystykę aktywną, turystykę kwalifikowaną; w Unii Europejskiej niektórzy specjaliści turystyki usportowionej określają ją jako sport dla wszystkich. Wśród badaczy zajmujących się tą dziedziną panuje zgodność, że celem uprawiania turystyki usportowionej jest wypoczynek, rekreacja, doskonalenie sprawności, wydolności i zdrowia oraz wszechstronne poznanie kraju i świata ${ }^{6}$.

Turystyka usportowiona wymaga od uczestników pewnego wysiłku fizycznego, kondycji psychicznej i umiejętności posługiwania się odpowiednim sprzętem. Nie chodzi w niej jednak o charakter wyczynowy, ale o wypoczynek, rekreację, doskonalenie sprawności, wydolności i zdrowia. Jej założeniem jest również poznanie środowiska, stąd też jest formą, która najbardziej odpowiada celom wychowawczym i kształcącym. Odrębność tej formy turystyki polega również na tym, że jej miejscem są szczególnie atrakcyjne tereny, a często także zbudowane przez człowieka ośrodki turystyczne i sportowe. Od sportu różni się brakiem współzawodnictwa i pogoni za coraz lepszym wynikiem.

Należy jednak doszukiwać się wspólnych elementów w sporcie masowym, rekreacyjnym, który polega na systematycznym uprawianiu ćwiczeń fizycznych według określonych reguł z elementami współzawodnictwa. Wyróżnia się on przy tym tendencją do osiągania coraz lepszych wyników oraz do polepszenia sprawności i wydolności fizycznej?.

Specjalnie dobrany system ćwiczeń fizycznych uzupełnia zbyt jednostronną nieraz działalność fizyczną turysty lub jest wykorzystywany dla przygotowania sprawności specjalistycznej w okresach między poszczególnymi sezonami ${ }^{8}$.

\section{Wydarzenia - efektowna forma promocji}

Promocja w turystyce wpływa w dużym stopniu na rozwój danego obszaru, a także na zwiększenie ruchu turystycznego. Poza klasycznymi formami promocji coraz częściej docenia się możliwość wykorzystania nowych, bardziej

${ }_{6}$ W. Siwiński, Współczesne problemy turystyki i rekreacji w badaniach empirycznych nauk społecznych, Almamer, Warszawa 2007, s. 14.

7 J. Merski, J. Warecka, Turystyka kwalifikowana, turystyka aktywna, Almamer, Warszawa 2009, s. 25.

8 J. Merski, op.cit., s. 25. 
efektownych, niestandardowych form, do których można zaliczyć event marketing (marketing wydarzeń, organizację imprez).

Wydarzenie to produkt turystyczny, który może istnieć samodzielnie lub być częścią składową produktu turystycznego, charakteryzuje się dużą spójnością tematyczną, organizacyjną oraz konkretnym umiejscowieniem w czasie i przestrzeni. Typowa dla wydarzeń jest niecodzienność, wyjątkowość i niekiedy cykliczność występowania9.

Pierwotnie słowo event oznaczało jakieś szczególne wydarzenie określane jako wyjątkowe, spektakularne, niezapomniane. Obecnie eventy definiuje się jako zorganizowane, celowe, ograniczone czasowo różnego rodzaju wydarzenia, w których grupa osób bierze udział w miejscu jego realizacji lub dzięki transmisji w mediach. Ponadto, eventy to wszelkie formy aktywności dotyczące organizowania imprez o charakterze kulturalnym, gospodarczym, sportowym, politycznym lub naukowym, w czasie których dochodzi do interakcji10.

Dzięki organizacji imprez regiony umacniają swoją markę przez wypromowanie swoich walorów i oddziaływanie zarówno na wewnętrzne rynki docelowe (mieszkańcy, przedsiębiorcy), jak i rynki zewnętrzne (potencjalnych turystów, sponsorów).

W sferze marketingowej wyróżnia się następujące pozytywne efekty eventów ${ }^{11}$ :

- wzrost świadomości, rozpoznawalności regionu,

- kreowanie pozytywnego wizerunku regionu,

- kreowanie marki regionu,

- kreowanie popytu na inne dobra i usługi regionu.

W ostatnich latach obserwuje się wzrost znaczenia wydarzeń komunikacji marketingowej, co wynika m.in. ze wzrastającej roli public relations w stosunku do innych instrumentów promocyjnych, w tym także reklamy. Stosowane działania w zakresie PR ulegają rozszerzeniu w czasie, a zarządzający ośrodkami organizują rozmaite imprezy zwracające uwagę na daną jednostkę, starając się przy tym o rozpowszechnienie pochlebnych przekazów czy artykułów w mediach ${ }^{12}$.

9 J. Kaczmarek, A. Stasiak, B. Włodarczyk, Produkt turystyczny, PWE, Warszawa 2005, s. 74.

${ }^{10}$ Marketing $w$ turystyce i rekreacji, red. A. Panasiuk, Wydawnictwo Naukowe PWN, Warszawa 2013, s. 238.

11 Ibidem, s. 241.

12 Por. W. Kuźniar, Obszary wykorzystania events marketingu w promocji walorów jednostki terytorialnej na przykładzie woj. podkarpackiego, w: Marketing przyszłości. Trendy. Strategie. Instrumenty. Partnerstwo i komunikacja w regionie, red. G. Rosa, A. Smalec, Zeszyty Naukowe Uniwersytetu Szczecińskiego 2010, nr 596, „Ekonomiczne Problemy Usług” nr 56, s. 360. 
Organizacja imprez sportowych to istotne narzędzie promocji ośrodków turystycznych wspierające ich dynamiczny rozwój. Przedsięwzięcia o charakterze sportowym dzięki rozwojowi mediów masowych stają się doskonałym nośnikiem informacji marketingowych, wzbudzając zainteresowanie potencjalnych odbiorców, a jednocześnie skutecznie oddziaływają na zachowania turystów. Organizacja takich imprez jest sposobem na osiągnięcie celów marketingowych, do których zaliczyć można zaprezentowanie turystom zachodzących pozytywnych zmian w danym regionie.

Miasta i gminy, a także organizacje zarządzające ośrodkami turystycznymi i sportowymi posługują się wydarzeniami przywiązanymi do miejsca, jedno- lub wielodniowymi, o zasięgu masowym, integrującymi uczestników, zwykle cyklicznymi i aktywnymi. Często widzą w nich narzędzie kształtowania wizerunku oraz podnoszenia atrakcyjności danego obszaru dla turystów.

Masowe imprezy sportowe to doskonała promocja dla danego obszaru, za czym idą korzyści ekonomiczne oraz poprawa wizerunku danego ośrodka. Gros imprez sportowych odbywa się w regionach turystycznych, dlatego turystyka zawsze będzie rozwijać się wraz ze sportem i należy traktować te działalności łącznie. Można stwierdzić, iż związek turystyki ze sportem jest ścisły. Prowadzenie promocji na fundamencie sponsorowania lub organizowania wydarzenia sportowego umożliwia realizowanie dwustronnej komunikacji z odbiorcami, dostęp do efektywnej reklamy, a także zapewnia obecność mediów i dodatkowe źródła przychodów.

Każda impreza jako punkt wyjścia dla działań promocyjnych ma również swoje słabe strony. Należy do nich zaliczyć m.in. krótki czas trwania, zaangażowanie i ryzyko organizacyjne, często brak powtarzalności, relatywnie wąskie oddziaływania na określaną grupę odbiorców ${ }^{13}$. Angażowaniu się w organizację wydarzeń sportowych dodatkowo może towarzyszyć konieczność poczynienia inwestycji związanych z rozbudową obiektów sportowych, a także infrastruktury komunikacyjnej oraz bazy hotelowej.

13 M. Gębarowski, Sport jako element działań promocyjnych polskich miast, w: Marketing przyszłości..., s. 343. 


\section{Jakuszyce - ośrodek narciarstwa biegowego}

Jakuszyce są dzielnicą Szklarskiej Poręby, w której znajduje się najbardziej znany ośrodek narciarstwa biegowego w Polsce - Polana Jakuszycka. Usytuowane są w rejonie Przełęczy Szklarskiej (886 m n.p.m.) znajdującej się pomiędzy Karkonoszami a Górami Izerskimi. Tradycje narciarstwa w Szklarskiej Porębie sięgają końca XIX w. i to tutaj w 1900 r. powstał pierwszy po śląskiej stronie gór klub narciarski „Windsbraut” - „Huragan”.

Okoliczne tereny Polany Jakuszyckiej słyną z niezwykle atrakcyjnego środowiska przyrodniczego. Szczególną uwagę należy zwrócić na obszary występowania gleb organicznych (torfowiska oraz namuły torfiaste), a także szatę roślinną - rośnie tu szereg roślin bagiennych, kilka gatunków turzyc oraz borówki. Osobliwością przyrodniczą są zwłaszcza torfowiska występujące na płaskich grzbietach - w 2000 r. utworzono rezerwat ścisły Torfowiska Doliny Izery. Rezerwat ten obejmują torfowiska wiszące typu wysokiego oraz przejściowego o łącznej powierzchni ok. 100 ha i ciągnące się wzdłuż Izery na długości ok. $3,2 \mathrm{~km}$ i szerokości do $0,8 \mathrm{~km}$ na wysokości ok. 840-850 m n.p.m. Poczynając od północy torfowiska, noszą nazwy: Borowina, Izerskie Bagno, Wręgi, Izerska Łąka oraz Kobyla Łąka. Poza rezerwatem znajduje się jeszcze kilka pomniejszych bagnisk i torfowisk nieleżących już w dolinie rzeki (np. Zielony Kąt) ${ }^{14}$.

Ośrodek turystyczny Polana Jakuszycka jest miejscem, gdzie od blisko 40 lat Stowarzyszenie Bieg Piastów organizuje liczne imprezy sportowe zarówno o charakterze międzynarodowym, jak i mniejszych, o charakterze krajowym czy regionalnym. Specyficzny mikroklimat sprzyjający długiemu zaleganiu pokrywy śnieżnej w tym regionie sprawia, że Jakuszyce cieszą cię znaczną popularnością wśród osób uprawiających turystykę kwalifikowaną. Organizowane imprezy sprawiają, że narciarstwo biegowe z roku na rok, również dzięki sukcesom J. Kowalczyk, zyskuje nowych zwolenników w różnych grupach wiekowych. Trasy biegowe w Jakuszycach to doskonałe warunki do uprawiania narciarstwa biegowego zarówno dla amatorów, jak i wyczynowców. Ośrodek ten oferuje trasy biegowe o różnym stopniu trudności, o łącznej długości blisko $100 \mathrm{~km}$. Większość tras położona jest w Górach Izerskich na terenie Nadleśnictwa Szklarska Poręba i częściowo Nadleśnictwa Świeradów-Zdrój.

${ }^{14} \mathrm{http} / / / w w w . i z e r a . p l /$ rezerwat.html (8.01.2015). 
Najbardziej znanym wydarzeniem sportowym organizowanym na Polanie Jakuszyckiej jest Bieg Piastów - najstarsza i największa w Polsce impreza narciarska, która każdego roku przyciąga kilka tysięcy osób w różnym wieku, zarówno z Polski, jak i z zagranicy. Największy masowy bieg narciarski w Polsce miał swoją premierę w 1976 r. i wystartowało w nim wówczas niewiele ponad pół tysiąca uczestników. Od tamtego czasu liczba uczestników tej imprezy systematycznie rosła, podobnie jak renoma samego biegu. W 1995 r. Stowarzyszenie Bieg Piastów spotkało znaczące wyróżnienie, gdyż Bieg Piastów został włączony do Europejskiej Ligi Biegów Długodystansowych - EUROLOPPET. Organizacja ta skupia 12 największych biegów narciarskich rozgrywanych w 8 krajach Europy.

Polana Jakuszycka jako jedyny w Polsce ośrodek narciarstwa biegowego posiada światową homologację FIS tras wyczynowych. Szczególnie istotny jest fakt, iż światowy certyfikat jakości tras FIS jest przepustką do ubiegania się o organizację zawodów Pucharu Świata, mistrzostw świata w narciarstwie klasycznym czy Pucharu Kontynentalnego.

$\mathrm{Na}$ Polanie Jakuszyckiej zaczynają się również trasy zawodów biatlonowych czy sportach zaprzęgowych. Szklarska Poręba jako jeden z nielicznych polskich ośrodków posiada doskonałe warunki do uprawiania jazdy psimi zaprzęgami. Corocznie na Polanie Jakuszyckiej odbywa się impreza Border Rush będąca jednym z najtrudniejszych europejskich średniodystansowych wyścigów. Atutem ośrodka jest specyficzny, alpejski klimat, dzięki któremu psy ras północnych czują się w tym regionie jak w swoim naturalnym środowisku.

Stowarzyszenie Bieg Piastów jako zarządca ośrodka narciarskiego Polana Jakuszycka stale poszukuje źródeł finansowania na utrzymanie tras biegowych oraz infrastruktury niezbędnej do przeprowadzania zawodów. Do źródeł tych należą pieniądze zarówno ze środków Unii Europejskiej oraz samorządu województwa dolnośląskiego, jak i z umów sponsorskich (m.in. KGHM Polska Miedź, PKO BP).

\section{Letni Bieg Piastów}

Ośrodek w Jakuszycach dostrzega możliwości popularyzowania lokalnych walorów przyrodniczych i miejsc szczególnie atrakcyjnych dla turystów preferujących aktywny styl spędzania wolnego czasu również w sezonie letnim. W programie rozwoju Polany Jakuszyckiej wskazuje się na turystykę kwalifikowaną 
jako jedną z form turystyki pozwalającą na zwiększenie ruchu turystycznego poza sezonem zimowym.

Od wielu lat trasy narciarskie Polany Jakuszyckiej w sezonie letnim wykorzystywane są jako szlaki turystyki górskiej oraz ścieżki rowerowe. Na licznych szlakach turystycznych położonych w Jakuszycach z roku na rok przybywa miłośników turystyki górskiej oraz turystyki rowerowej. Przed amatorami wędrówek otworem stoją niezmierzone przestrzenie praktycznie całych Gór Izerskich. Warto przy tym nadmienić, że od pewnego czasu ułatwione jest przechodzenie na czeską stronę dzięki działającym przejściom turystycznym w Worku Jakuszyckim (do Harrachova) oraz przez mostek na Izerze w okolicach schroniska Orle (do Izerki).

Stowarzyszenie Biegu Piastów od kilku lat poszukiwało letniej alternatywy dla swojej flagowej imprezy narciarskiej - Biegu Piastów, choć próby organizacji biegów letnich w Górach Izerskich podejmowano już kilka lat wcześniej. W sierpniu 2013 r. odbył się pierwszy Letni Bieg Piastów obejmujący dwa biegi - Jakuszycką Dziesiątkę (10 km) oraz Półmaraton Górski (21 km). Ze względu na fakt, iż wiosną i latem w Górach Izerskich trwa okres ochronny cietrzewia, organizatorzy biegu musieli uzyskać zgodę służb ochrony środowiska na jego zorganizowanie, a służby te zezwoliły na start jedynie 500 osób.

$\mathrm{W}$ drugiej edycji biegu pomimo stosownych regulacji prawnych dotyczących ochrony środowiska na tym terenie limit uczestników został zwiększony do 700 osób. Ze względu na uwarunkowania środowiskowe w Półmaratonie Górskim uczestniczyło 500 osób, a w Jakuszyckiej Dziesiątce - 200 osób.

W przypadku Letniego Biegu Piastów celem Stowarzyszenia jest to, aby Polana Jakuszycka tętniła życiem przez cały rok tak jak w sezonie zimowym. Letni Bieg Piastów to bieg wyjątkowy, przebiegający jedynie po leśnych ścieżkach Gór Izerskich. Dla amatorów tej formy aktywności jest to okazja do biegania na trasach, które zimą wybierają najlepsi zawodnicy narciarstwa biegowego. Bieg ten przyciąga uczestników cudownymi widokami, ciekawymi podbiegami i ostrymi zbiegami, co wyraźnie odróżnia go od innych imprez biegowych w Polsce. Założeniem organizatorów jest stworzenie imprezy cyklicznej, odbywającej się zawsze w ostatnią sobotę sierpnia, pół roku po zimowym Biegu Piastów.

Letni Bieg Piastów jest odpowiedzią organizatorów na coraz bardziej popularną w naszym kraju aktywność biegową. Niezwykłość tej aktywności polega również na tym, że bieganie można uprawiać niemal wszędzie. Żeby 
zorganizować dużą imprezę biegową, nie ma potrzeby budowania ogromnych i kosztownych aren sportowych. Należy wytyczyć i przygotować atrakcyjną trase w lesie, parku czy górach. Jednocześnie bieganie to aktywność dająca możliwość wspólnej rywalizacji zawodników wyczynowych i zupełnych amatorów.

Stowarzyszenie Biegu Piastów nie dysponuje jednak środkami umożliwiającymi intensywne działania promocyjne. Podejmując określoną aktywność promocyjną, organizator biegu bierze pod uwagę to, iż przekazy odwołujące się do rywalizacji sportowej (turystyki usportowionej) są w stanie przyciągnąć określoną, stosunkowo wąską grupę osób. Szczególnie widoczne jest kierowanie szczegółowych informacji do wybranej grupy turystów aktywnych, często związanych z działalnością Stowarzyszenia w sezonie zimowym. Przekaz promocyjny trafia bezpośrednio do osób, które wybierają sobie kilka form rekreacji ruchowej, np. biegi narciarskie zimą oraz bieganie latem.

Letni Bieg Piastów jest kierowany zarówno do mieszkańców regionu zainteresowanych jednodniowym aktywnym wypoczynkiem, jak i turystów z dalszych regionów zainteresowanych wyjazdami weekendowymi. Analiza miejscowości, z których pochodzili uczestnicy drugiej edycji biegu, wskazuje, że zdecydowana większość przybyła z miast oddalonych od Szklarskiej Poręby o ponad 100 km, np. Wrocławia (110 uczestników), Poznania (33 uczestników), Krakowa (15 uczestników) czy Warszawy (14 uczestników).

Tabela 1

Liczba uczestników Letniego Biegu Piastów w podziale na miejscowości

\begin{tabular}{|c|c|c|}
\hline Lp. & Miasto & Liczba uczestników \\
\hline 1. & Wrocław & 110 \\
\hline 2. & Jelenia Góra & 89 \\
\hline 3. & Poznań & 33 \\
\hline 4. & Szklarska Poręba & 20 \\
\hline 5. & Bogatynia & 18 \\
\hline 6. & Piechowice & 17 \\
\hline 7. & Kraków & 15 \\
\hline 8. & Warszawa & 14 \\
\hline 9. & Gołdap & 13 \\
\hline 10. & Lubin & 11 \\
\hline
\end{tabular}

Źródło: www.online.datasport.pl/zapisy/portal/listy/stats.php?zawody=995\# (1.09.2014). 
Działania Stowarzyszenia Biegu Piastów w zakresie organizacji Letniego Biegu Piastów zostały dostrzeżone również przez środowisko biegowe. Pierwsza edycja Letniego Biegu Piastów została uhonorowana nagrodą Brązowa Kozica za organizacyjny debiut roku (nagroda portalu biegigorskie.pl). Od drugiej edycji Półmaraton Górski odbywający się w ramach Letniego Biegu Piastów stał się jednocześnie finałem prestiżowego cyklu biegów trailowych Salomon S-LAB. W jego skład poza jakuszyckimi zawodami wchodzą: Maraton Gór Stołowych oraz Dolnośląski Festiwal Biegów Górskich Ziemi Kłodzkiej (trzy biegi: 7 Szczytów, Złoty Maraton i Złoty Półmaraton).

Kampania promocyjna ośrodka turystycznego oparta na organizowaniu masowej imprezy sportowej umożliwia organizatorom dostęp do efektywnej komunikacji poprzez obecność środków masowego przekazu oraz zainteresowanie potencjalnych sponsorów. Letni Bieg Piastów, podobnie jak inne niekomercyjne imprezy masowe o dużym zasięgu, funkcjonuje w dużej mierze dzięki wsparciu sponsorów. Druga edycja biegu wsparta została m.in. przez PKO BP SA, producenta odzieży sportowej Salomon oraz producenta wody źródlanej Wojcieszowianka.

\section{Podsumowanie}

W Polsce z roku na rok organizuje się coraz więcej imprez biegowych. Zaczyna tworzyć się ,rynek biegowy”, na którym organizatorzy biegów zaczynają konkurować o uczestników, sponsorów, media oraz przychylność lokalnej społeczności. Coraz większego znaczenia nabiera profesjonalizm organizacji takich wydarzeń, a także wykorzystanie zasad i narzędzi marketingu sportowego.

Stowarzyszenie Bieg Piastów traktuje turystykę usportowioną i rekreację jako kluczowy atut produktu turystycznego Jakuszyc. Aby zachęcić potencjalnych turystów do odwiedzenia Polany Jakuszyckiej poza sezonem zimowym, stara się wykorzystywać odpowiednie instrumenty promocyjne. Wzrastające zainteresowanie Letnim Biegiem Piastów bezsprzecznie wskazuje na kluczową rolę tej imprezy w promocji turystycznych atutów regionu.

Dzięki tej imprezie Stowarzyszenie Bieg Piastów rozpowszechnia informację wśród konkretnych odbiorców o możliwościach wykorzystania bazy sportowo-rekreacyjnej Polany Jakuszyckiej również w sezonie letnim. W najbliższych latach planowana jest modernizacja i znacząca rozbudowa infrastruk- 
tury ośrodka. Zgodnie z przyjętą koncepcją powstaną dwa duże nowoczesne obiekty - jeden przeznaczony dla sportu wyczynowego, drugi dla amatorskiego - z miejscami na szatnie, sanitariaty, gastronomię, pomieszczenia techniczne i hotelowe, a także mediów i VIP-ów. Na Polanie Jakuszyckiej powstanie również stadion zimowy oraz przejścia podziemne, które będą integralną częścią ośrodka i umożliwią bezkolizyjne korzystanie z tras wyczynowych i amatorskich. Celem Stowarzyszenia Biegu Piastów jest zatem rozwój Jakuszyc zarówno w zakresie imprez zimowych, jak i wydarzeń sportowych, które będą odbywać się w sezonie letnim.

\section{Literatura}

Gębarowski M., Sportjako element działań promocyjnych polskich miast, w: Marketing przyszłości. Trendy. Strategie. Instrumenty. Partnerstwo i komunikacja w regionie, red. G. Rosa, A. Smalec, Zeszyty Naukowe Uniwersytetu Szczecińskiego 2010, nr 596, „Ekonomiczne Problemy Usług” nr 56.

Kaczmarek J., Stasiak A., Włodarczyk B., Produkt turystyczny, PWE, Warszawa 2005.

Kuźniar W., Obszary wykorzystania events marketingu w promocji walorów jednostki terytorialnej na przykładzie woj. podkarpackiego, w: Marketing przyszłości. Trendy. Strategie. Instrumenty. Partnerstwo i komunikacja w regionie, red. G. Rosa, A. Smalec, Zeszyty Naukowe Uniwersytetu Szczecińskiego 2010, nr 596, „Ekonomiczne Problemy Usług” nr 56.

Marketing $w$ turystyce i rekreacji, red. A. Panasiuk, Wydawnictwo Naukowe PWN, Warszawa 2013.

Merski J., Wptyw uprawiania turystyki kwalifikowanej przez ludzi dorostych na ich sprawność motoryczna, Almamer, Warszawa 2007.

Merski J., Warecka J., Turystyka kwalifikowana, turystyka aktywna, Almamer, Warszawa 2009.

Siwiński W., Wspótczesne problemy turystyki i rekreacji w badaniach empirycznych nauk spotecznych, Almamer, Warszawa 2007.

Tomik R., Hadzik A., Cholewa J., Turystyka aktywna w materiatach promocyjnych województw w Polsce, w: Wyzwania współczesnej polityki turystycznej. Problemy polityki turystycznej, red. A. Rapacz, Wyd. UE we Wrocławiu, Wrocław 2012.

Winiarski R., Zdebski J., Psychologia turystyki, Wydawnictwa Akademickie i Profesjonalne, Warszawa 2008.

www.izera.pl/rezerwat.html.

www.online.datasport.pl/zapisy/portal/listy/stats.php?zawody=995\#. 


\title{
THE ORGANIZATION OF MASS SPORT EVENTS AS THE FORM OF SPORT CENTRES PROMOTION BASED ON THE EXAMPLE OF SUMMER PIASTS' RACE IN JAKUSZYCE
}

\begin{abstract}
Summary
The purpose of this paper is to present the possibilities for tourism product promotion using the modern promotional form called event marketing. The initial, introductory part of the article presents the problems of sport oriented tourism and its similarities with sport and qualified tourism. The author has also discussed the essence and qualities of activities related to even marketing. Next the author characterized Jakuszyce as the most popular centre for cross-country skiing in Poland and the Association of Piasts' Race - the organizer of the biggest sport events in the area of Jakuszycka Clearing. The final part of the article covers the activities related to the organization of Summer Piasts' Race and this event impact on the development of tourism in Jakuszyce in summer season.
\end{abstract}

Keywords: tourism promotion, qualified tourism, event marketing, Summer Piasts' Race 
